\title{
Yaşam Doyumu İle İşgören Performansı İlişkisini İncelemeye Yönelik Bir Alan Araştırması
}

\author{
A Field Research for Examining the Relationship Between Life Satisfaction And Employee Performance \\ Gökhan Uludağ ${ }^{a^{*}}$

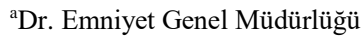 \\ ORCID: 0000-0003-4763-7511
}

\section{MAKALE BİLGİṠ \\ Makale Geçmişi: \\ Başvuru tarihi: 1 Şubat 2019 \\ Düzeltme tarihi: 02 Temmuz 2019 \\ Kabul tarihi: 17 Temmuz 2019}

\section{Anahtar Kelimeler:}

Yaşam Doyumu

İşgören Performansı

Verimlilik
ÖZ

Günümüzde yeni yönetim anlayışları ile birlikte insanların önemi de giderek artmıştır. Organizasyonlar bir yandan teknolojik yenilikleri yakalamaya çalışmakta ve fiziki şartlarını geliştirmeyi hedeflerken diğer yandan çalıştırdığı işgörenlerinden en üst düzeyde performans almayı hedeflemektedir. İşgörenlerin performansları çeşitli yöntemlerle artırılabilir. İşgörenlerin performansları üzerinde etki eden faktörlerden birisi de yaşam doyumudur. $\mathrm{Bu}$ nedenle yöneticilerin işgörenlerin yaşam doyumunu artırmaya yönelik çalışmalar yapması gerekmektedir. $\mathrm{Bu}$ araştırmanın amacı; yaşam doyumu ile işgören performansı arasındaki ilişkiyi tespit etmek ve işgören performansı üzerinde yaşam doyumunun etkisini ortaya koyabilmektir. Bu kapsamda, Ankara'da faaliyet gösteren Ankara İl Gençlik ve Spor Müdürlüğü personelleri üzerinde anket yoluyla veriler toplanmıştır. Araştırmanın sonucunda, yaşam doyumu ile işgören performansı arasında anlamlı ve pozitif yönde bir ilişki olduğu ve demografik değişkenler arasında farklılık olduğu tespit edilmiştir

\section{A B S T R A C T}

Today, the importance of people with new management concepts has increased. Organizations aim to achieve the highest level of performance from the employees they work on, while aiming to improve technological conditions and to improve their physical conditions. Employees' performances can be increased by various methods. One of the factors affecting the performance of employees is life satisfaction. Therefore, managers need to work to increase the life satisfaction of employees. The purpose of this research; to determine the relationship between life satisfaction and employee performance and to demonstrate the effect of life satisfaction on employee performance. In this context, data were collected by means of surveys on Ankara Provincial Youth and Sports Directorate personnel operating in Ankara. As a result of the study, it was determined that there was a significant and positive relationship between life satisfaction and employee performance and there was a difference between demographic variables.

\section{Giriş}

Günümüz iş hayatı içerisinde işgörenlerin sergilediği performans organizasyonların rekabet gücünde önemli bir gösterge olarak olarak belirtilebilir (Wang ve Netemeyer, 2002: 217). İstikrarlı bir şekilde performansın korunabilmesi ve hatta artırılabilmesi için; değişimin çok hızlı gerçekleştiği günümüzde hem insanların hem de organizasyonların bu değişime ayak uydurması gerekmektedir.

Bir organizasyonun ekonomik kaynakları ve fiziki şartları ne kadar iyi olursa olsun ürünü ortaya koyabilecek yüksek kapasiteli işgörenleri olmadığı sürece başarısız olma ya da beklediği karşılığı alamama durumu söz konusu olabilir. Bu durum organizasyon açısından insan unsurunun ne kadar önemli olduğunu yansıtmaktadır.

Organizasyon içindeki işgörenlerin, işlerin yerine getirilmesinde gerekli olan sayısından ziyade işe uygunlukları ve kendilerinden beklenilen performansı ortaya koyabilmeleri çok daha önemlidir. İşgörenlerden maksimum düzeyde performans alabilmek için yöneticilerin doğru analizlerde bulunması, hissi davranmaması ve profesyonel davranış sergilemeleri gerekmektedir. Bu doğrultuda işgörenleri kendi uzmanlık alanlarında görevlendirmeleri ve adaletli bir yönetim anlayışının organizasyon içerisinde kabul görmesi önemli hususlardandır.

\footnotetext{
* Sorumlu yazar/Corresponding author

e-posta: guludagg@hotmail.com
} 
Yönetim anlayıșında ortaya çıkan yeni yaklașım ve modeller işgörenlerin performansları üzerinde etkili olabilmektedir. İnsanların yaşam içerisinde karşılaştıkları çeşitli olaylar, hayata bakışını, moral düzeyini, zihinsel kontrolünü ve insanlarla olan ilişkilerini etkileyebilmektedir.

İnsanların hayata pozitif bakabilmeleri için yaşam doyumuna ulaşmaları gerekmektedir. Yaşam doyumuna ulaşamayan işgörenlerin günlük yaşantı içerisinde mutsuz olması, kendisini huzursuz hissetmesi ve konsantrasyon sorunları yaşaması oldukça normaldir ve bu gibi durumlar sergiledikleri performansı etkileyebilmektedir.

İşgörenlerin özellikle iş dışında yaşadığı travmatik olaylar; (ölüm, ayrılık, sağlık problemleri vb.) yaşam doyumunu olumsuz etkileyerek, uzun sürede kişilerin kendilerini toparlamalarını ve işe tam anlamıyla konsantre olmalarını etkileyecektir ve işgörenlerin performanslarının düşmesine yol açacaktır. Yöneticilerin işgörenlerin yaşam doyumunu olumsuz etkileyecek durumlarla yakından ilgilenmeleri, gerekli uzmanlar aracılığıyla yardım almalarını sağlamaları performans düzeyinin korunması ve hatta artması noktasında büyük bir öneme sahiptir. İşgörenlerin sorunları ile ilgilenmek ve yaşam doyumunu artırmaya çalışmak bir organizasyonun rakiplerine göre rekabet avantaj1 elde etmesi noktasında ilgi göstermesi gereken konulardan birisidir.

\section{Teorik Çerçeve}

\subsection{Yaşam Doyumu}

Sosyal yaşam içerisinde insanlar çok faklı olaylarla karşılaşabilirler. $\mathrm{Bu}$ olaylar istemediğimiz olaylar ise; işyerinde arkadaşlarımızla tartışmak, yolda giderken araç lastiğinin patlaması, aile fertlerinden birinin rahatsızlanması ve hatta ölmesi, ekonomik açıdan zarara uğramak vb. gibi durumlar insanların mutsuz olmasına neden olur ve belirli bir süre bu mutsuzluk devam edebilir. Buna karşılık, işyerinde iyi bir iletişim ağına sahip olmak, aile içerisinde sağlık ve huzurlu bir ortamın olması, istediklerini tedarik edebilme vb. gibi durumlar insanların mutlu olmasına ve hayata pozitif bakabilmesini sağlayabilmektedir. İnsanların devam eden yaşantıları üzerinde sağlıklı düşünebilmeleri ve konsantre olmaları noktasında yaşamdan doyum elde etmeleri oldukça önemlidir. Bu nedenle yaşam doyumu kavramı giderek önem kazanmaktadır.

İlk kez Neugarten (1961:134) tarafından ileri sürülen yaşam doyumu kavramı ya da kullanımı itibariyle mutluluk, uzun yıllar boyunca insanlığın ilgisini çeken konulardan birisi olmuştur. Yaşam doyumu, bir kişinin beklentileriyle, sahip olduklarının kıyaslanmasıyla ortaya çıkan sonuçtur. Yaşam doyumu, genel açıdan insanların tüm yaşamını ve bu yaşamın çok çeşitli yönlerini kapsamaktadır. Yaşam doyumu kavramından bahsedildiğinde, belirli bir durumla ilgili doyum değil, genel itibariyle tüm yaşantılardaki doyum kastedilmektedir (Özer ve Karabulut, 2003: 72-73). İnsanlar makinalar gibi programlanabilen varlıklar değildir. Bunun başlıca nedeni yaşamlarına yön veren duygulara sahip olmalarıdır. Kısa süre önce mutlu olan birisinin özel durumlar dışında kısa bir süre sonra mutsuz olması düşünülemez. Bu nedenle yaşam doyumu geneli kapsayan bir olgudur.

Yaşam doyumu kavramı ile ilgili çok sayıda tanım mevcuttur. $\mathrm{Bu}$ tanımlardan bazıları şu şekildedir. Yaşam doyumu; insanların karşısına çıkan yaşam şartları ve başından geçen olaylardan kazandığı tecrübelerinin etkileşiminden elde ettiği sonuçlara göre değişim gösteren amaçları ile yerine getirdikleri, kazandıkları arasındaki algıladığı fark olarak belirtilmektedir (Dündar, 1993:50). Veenhoven (1996:14) yaşam doyumunu kişilerin şahsi yaşamlarını ve yaşam tarzlarını analiz ederken pozitif ve olumlu bir yaklaşım içinde bulunmalarıdır şeklinde tanımlamıştır.

Yaşam doyumu, insanın mutluluğu ile alakalı unsurlardan öznel iyi oluşun bilişsel yönüne işaret etmektedir. Öznel iyi oluş, insanın yaşantısını bilişsel ve duygusal açıdan analiz etmesi olarak ifade edilmektedir. $\mathrm{Bu}$ analiz, olaylara karş1 gösterilen duygusal tepkileri ve doyumun bilişsel analizini kapsamaktadır. Yaşam doyumu kişinin kendi tercih ettiği ölçütlere göre yaşamının niteliği hakkındaki genel analizler olarak belirtilmektedir. Yaşam doyumu mevcut devam eden yaşamdan doyum, yaşamı değiştirme arzusu, geçmiş ve gelecekten doyum ve kişinin yakın çevresinden o kişinin yaşamına yönelik bakış açısını içermektedir. Doyum alanları iş hayatı, aile içi yaşam, serbest zaman değerlendirme, sağlıklı yaşam, sahip olunan para, kişisel benlik ve kişinin yakın çevresi şeklinde ifade edilebilmektedir (Dost, 2007: 133). İnsanların farklı yönlerinin birbiri ile uyum içerisinde olması oldukça önemlidir. Bir taraftan ekonomik güce sahip iken öbür yandan aile içi huzursuzlukların olması yaşam doyumunu olumsuz etkileyecektir. Zhao, Qu ve Richard (2011: 50) meydana gelen olumsuz durumların ve etkilerinin doğurduğu negatif hislerin insanların yaşam doyumunu düşüreceğini ifade etmiştir. Bu nedenle olumsuz durumların giderilmeye çalışılması yaşam doyumunu yükseltmek adına olumlu sonuçlar doğurabilir.

\section{2. İşgören Performans1}

Günlük yaşam içerisinde de sık sık kullandığımız bir kavram olan performans organizasyonlar açısından daha fazla önem arz eden bir kavramdır. Sektöründe zirveye ulaşmak isteyen organizasyonların işgörenlerinden yüksek düzeyde performans almaları gerekmektedir.

Performans kavramı birçok disiplini ilgilendirmesi nedeniyle çok sayıda tanımı yapılmıştır. Performans, bir işi yürüten işgörenin, bir organizasyonun veya özel grubun, belirlenen görev ile gidilecek amaca göre nelere ulaşabildiği nicel ve nitel yapıda karşımıza çıkan bir kavramdır (Benligiray, 2011:149). Performans kavramı, amaçları ve hedefleri yakalayabilme, gerçekleşme seviyesi şeklinde ifade edilmektedir. Bir başka ifade ile performans kavramı, organizasyonlar açısından belirli bir süre içerisinde üretilen ürün veya hizmetin oranı şeklinde belirtilirken, şahıslar açısından performans; amaç ve hedeflere ulaşma hususunda sergilenen bireysel "verimlilik" ve "etkinlik" seviyesi olarak belirtilmektedir (Tutar ve Altınöz, 2007: 201). Diğer bir tanımda da; işgörenlerin ve üstlerinin aralarında geçen ve dış çevreyle olan münasebetleri, makine ve donanımların şartları, sisteme ilişkin uygulanan yöntem vb. ile olan ilişkilerin tamamıdır (Engin, 2008: 51). İşgören performansı, işin bir unsuru olarak işgörenlerin işe yönelik faaliyetleri ile ilgilidir. Alacakları ücrete mukabil yapmaları gereken çaba olarak belirtilmiştir (Bekiş, Bayram ve Şeker 2013: 20). Bütün tanımlardan anlaşılacağı üzere belirli bir karşılık mukabilinde ortaya konulan emek olduğu karşımıza çıkmaktadır. 
İşgörenlerin performanslarının yönetimi organizasyonlar için büyük bir öneme sahiptir. Başarılı bir performans yönetiminin gerçekleşmemesi, işgörenlerin taleplerinin karşılanamamasına neden olabilir. $\mathrm{Bu}$ nedenle, işgörenlerin bireysel performanslarının sağlıklı ve adaletli kriterler baz alınarak belirlenmesi, bu hususta işgörenlere yeterli bilgilendirmenin yapılması, bireysel üretkenliğin yükselmesi için işgörenlerin performanslarının geliştirilmesi yoluyla organizasyonun etkinliğinin daha üst seviyelere çıkarılması, etkili bir performans yönetiminin amaçları içerisinde yer almaktadır (Dehaghi ve Rouhani, 2014: 905). Bu nedenle işgörenlerin zaman zaman performans değerlendirme süreçlerinden geçirilmelerinde yarar olduğu söylenebilir.

Organizasyonların hizmet alanları ve pazar oluşturdukları kişiler açısından büyüklükleri faklı olsa bile yönetici konumunda olan kişiler için her zaman geçerli olan faktör; işgören performansının artırılmasıdır. Bu durum yöneticiler marifetiyle, iş gücünü organizasyonun ihtiyaçlarını gidermeye yönelik en verimli şekilde kullanılması olarak da ifade edilebilir. Ayrıca performans ölçüt alınırken; işgörenin görevini ifa ettiği yerde kendisine yönelik önceden belirlenmiş olan ve nitelikleri doğrultusunda kendisinden yerine getirilmesi beklenen işin ifa edilmesidir (Boylu ve Sökmen, 2002:168-169).

$\mathrm{Bu}$ doğrultuşa işgörenin yaşına, eğitim düzeyine, daha önceki iş tecrübesine ve duygusal tercihlerine bakılarak en uygun iş alanında değerlendirilmesi; daha fazla performans elde etmek açısından önemlidir.

\section{3. Yaşam Doyumu İle İşgören Performansı Arasındaki İlişki}

İnsanların yaşamlarında doyuma ulaşmaları oldukça önemlidir. Nitekim normal yaşamı içerisinde mutsuz, huzursuz, stres içerisindeki insanların herhangi bir işe konsantre olmalarının zor olacağı düşünülür.

İşgörenlerin performansı üzerinde etki eden çok sayıda unsur bulunmaktadır. Turnalı (2013:21-22) bunları; kişisel faktörler, örgütsel faktörler, çevresel faktörler olarak üçe ayırmaktadır. $\mathrm{Bu}$ faktörler incelendiği zaman yaşam doyumu kavramıyla bağlantılı olduğu görülmektedir. Özellikle kişisel faktörlerin yaşam doyumu ile içe içe olduğu görülecektir.

İnsanların bir işi yerine getirirken o anki ruh hali, stres düzeyi, zihninden atamadığı bir ailevi sorunu, huzursuzluğu ve mutsuz olması yaşam doyumunu etkileyen ve aynı zamanda performansı da etkileyen unsurlardır. Bu nedenle yaşam doyumu ile işgören performansının belirli değişkenler doğrusunda birlikte artarak birlikte azalacağı düşünülebilir.

İnsanlar duyguları doğrultusunda hareket eden ve duyguları tarafından harekete geçirilen varlıklardır. Bireyin hayatının her alanındaki tatmini veya tatminsizliğinin alt yapısında duygular önemli bir yer oynamaktadır (Çınar ve Özyılmaz, 2019:541). Bu doğrultuda İnsanların sahip oldukları duyguları itibariyle bir bütün olarak değerlendirilmesi gerekmektedir. $\mathrm{Bu}$ nedenle iş dışında karşıllaşılan travmatik durumların işe yansıtılmaması oldukça zordur. Önemli olan bu durumların seviyesinin düşürülerek kişinin işine yansıtmamasının sağlanmasıdır. $\mathrm{Bu}$ da yaşam doyumu ile ilgilidir.

\section{Araştırmanın Metodolojisi}

\subsection{Araştırmanın Amacı ve Önemi}

Araştırmanın amacı, yaşam doyumu ve işgören performansını ele almak ve işletmelerde işgörenler arasındaki bu ilişkileri ortaya koymaktır.

Devlet işlerinin sistematik olarak gerçekleştirildiği ülkelerde olduğu gibi ülkemizde de halkın taleplerinin karşılanması ve hizmet götürülmesi için hizmet eden kurumlar bulunmaktadır. $\mathrm{Bu}$ kurumlarda çalışan işgörenlerin sergiledikleri performans ne kadar üst seviye olursa ortaya çıkan hizmetin kalitesi de o derece üst seviyede olacaktır.

Bu araştırma da Ankara İl Gençlik ve Spor Müdürlüğünde işgörenlerin yaşam doyumunun hangi düzeyde olduğunun ölçülmesi ve performans seviyesinin artırılması noktasında yaşam doyumu ile işgören performansının ilişkinin tespit edilmesi için oldukça önemlidir. Literatürde yaşam doyumunun; işgören performansı üzerinde etkisine yönelik yapılan çalışmalara, sonuçları ile kıyaslanması açısından katkı sağlaması beklenilmektedir.

\subsection{Araştırmanın Evreni - Örneklemi}

Araştırma evrenini Ankara İl Gençlik ve Spor Müdürlüğü il merkezinde görev yapan toplam 500 personel oluşturmaktadır. Bu doğrultuda ilgili kamu kurum müdürü ile yüz yüze görüşme yapılarak gerekli izin alınmış olup, il müdürlüğünde görevli personel yardımıyla anket soruları görevde hazır bulunan 300 personele dağıtılmış, anketlerin doldurulmasının ardından anketler toplanmıştır. Toplanan anketlerden eksiksiz olarak gelen 220 anket değerlendirilmeye alınmıştır. Kurum personelin bir bölümünün periyodik şekilde görev yapmaları nedeniyle, personele; biriminde istenilen zamanda ulaşılamaması araştırmanın sınırlılığı olarak belirtilebilir. 


\subsection{Araştırmanın Hipotezleri ve Modeli}

Araştırma kapsamında test edilen hipotezler şunlardır:

H1a. İşgörenlerin yaşam doyumu düzeyleri cinsiyet değişkeni açısından farklılık göstermektedir.

H1b. İşgörenlerin işgören performansı düzeyleri cinsiyet değişkeni açısından farklılık göstermektedir.

H2a. İşgörenlerin yaşam doyumu düzeyleri medeni durum değişkeni açısından farklılık göstermektedir.

H2b. İşgörenlerin işgören performansı düzeyleri medeni durum değişkeni açısından farklılık göstermektedir.

H3a. İşgörenlerin yaşam doyumu düzeyleri öğrenim durumu değişkeni açısından farklılık göstermektedir.

H3b. İşgörenlerin işgören performans1 düzeyleri öğrenim durumu değişkeni açısından farklılık göstermektedir.

H4a. İşgörenlerin yaşam doyumu düzeyleri yaş değişkeni açısından farklılık göstermektedir.

H4b.İşgörenlerin işgören performansı düzeyleri yaş değişkeni açısından farklılık göstermektedir.

H5a. İşgörenlerin yaşam doyumu düzeyleri çalışma süreleri değişkeni açısından farklılık göstermektedir.

H5b. İşgörenlerin işgören performansı düzeyleri çalışma süreleri değişkeni açısından farklılık göstermektedir.

H6a. İşgörenlerin yaşam doyumu düzeyleri görev unvanı değişkeni açısından farklılık göstermektedir.

H6b. İşgörenlerin işgören performansı düzeyleri görev unvanı değişkeni açısından farklılık göstermektedir.

H7. Yaşam doyumu ile işgören performansı pozitif ilişkilidir.

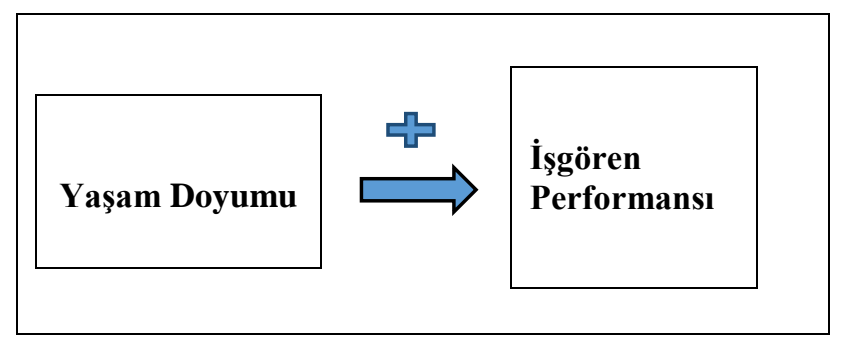

\section{Şekil 1.Araştırma Modeli}

\subsection{Araştırmanın Yöntemi ve Ölçüm Arac1}

Çalışma anket yoluyla yapılmıştır. Anket formunun birinci bölümü örneklemde yer alanların yaş, cinsiyet, öğrenim durumu, medeni durum, iş tecrübesi ve görevi gibi özelliklerin yer aldığı demografik bilgileri içermektedir.

Araştırma için, Diener, Emmons, Larsen ve Griffin (1985) tarafından geliştirilen "Yaşam Doyum Ölçeği' nin (YDO) Dağlı ve Baysa (2016) tarafindan Türkçe'ye uyarlanan 5 maddelik versiyonu kullanılmıștır. İstatiksel olarak anlamsız bulunan (3.) soru çıkartılmıştır. Yaşam doyum ölçeğinin güvenilirlik düzeyi; 0,830 olduğu ve kullanım açısından güvenilir olduğu görülmüştür. İşgörenlerin anket sorularını 'kesinlikle katılmıyorum (1), katılmıyorum (2), kararsızım (3), katıliyorum (4) ve kesinlikle katıllyorum (5)'şeklindeki 5 aralıklı likert ölçeği üzerinde cevaplamaları istenmiştir.

Üçüncü bölümde yer alan işgören performansı anketinde önce Kirkman ve Rosen (1999), daha sonra ise, Sigler ve Pearson (2000) tarafından yapılan çalışmalarda kullanılmış olan 4 sorudan oluşan anketten yararlanılmıştır. İşgören performansı ölçeğinin güvenilirlik düzeyi; 0,858 olduğu ve kullanım açısından güvenilir olduğu görülmüştür.

\subsection{Verilerin Analizi}

Verilerin değerlendirilmesinde SPSS 21.0 istatistik programı kullanılmıştır. Araştırmada elde edilen veriler, araştırmanın amacı doğrultusunda çeşitli istatistik metot ve test teknikleri (frekans dağılımı, ortalama, t-testi, anova, regresyon, korelasyon) kullanılarak yorumlanmıştır. Anova'da varyansların homojenliği durumunda scheffe, varyansların homojen olmaması durumunda ise tamhane's t2 çoklu karşılaştırma testleri kullanılmıştır. Verilerin değerlendirilmesi, katılımcıların her bir soruya verdikleri cevapların toplam puanları üzerinden yapılmış olup, istatistikî anlamlılık düzeyi $\mathrm{p}<0.05$ olarak kabul edilmiştir. 


\subsection{Bulgular}

Araştırmaya katılanların yüzdelik dilimini ve sayılarını tespit etmek amacıyla frekans alınmıştır.

Tablo 1. Demografik Değişkenlerin Frekans ve Yüzde Değerleri

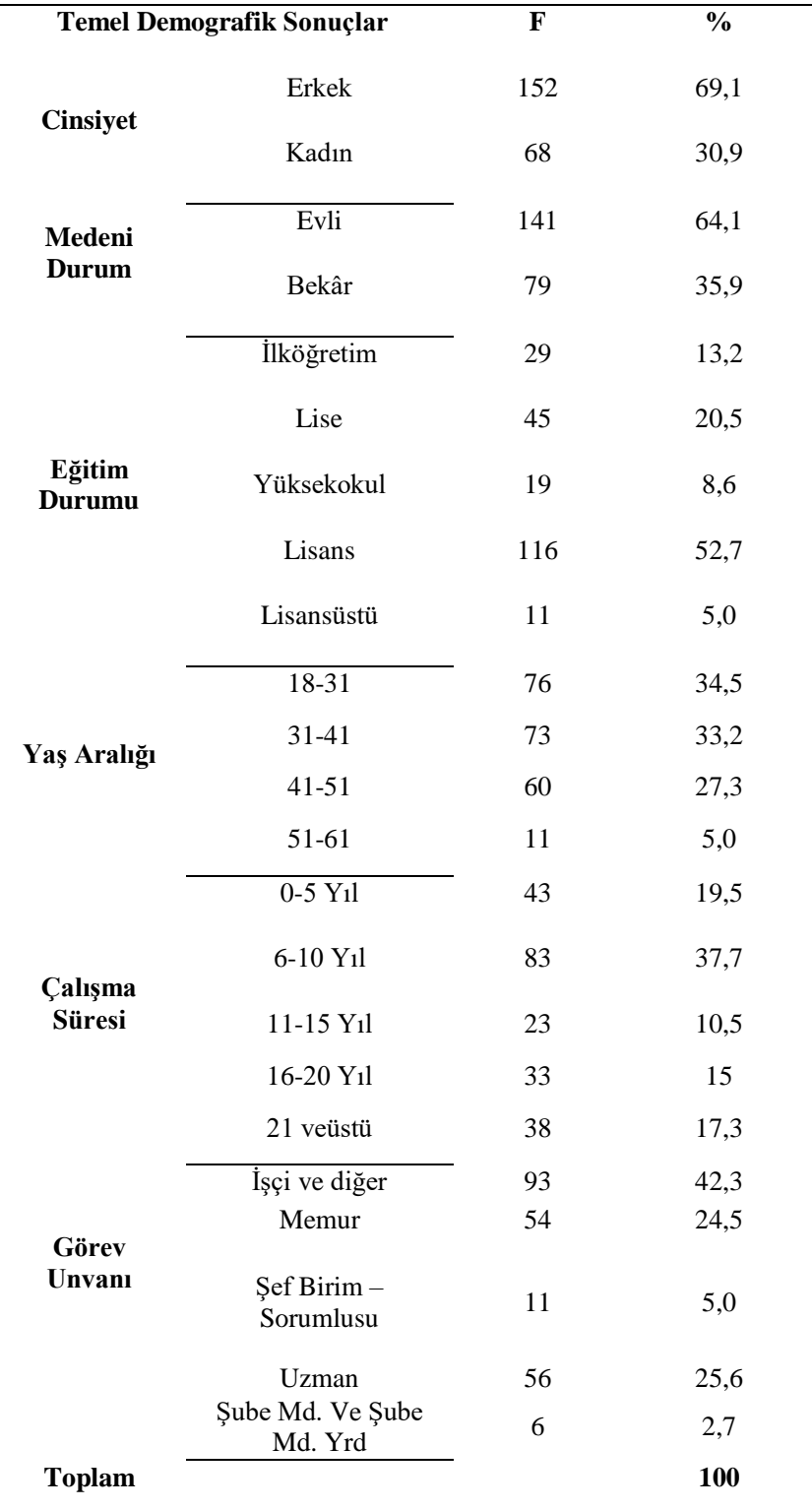

Araştırmaya katılanların \% 69.1'i erkeklerden oluşmakta olup 152 kişidir, \% 30.9'u ise kadınlardan oluşmakta olup 68 kişidir. Araştırmaya katılanların \% 64.1'i evlilerden oluşmakta olup 141 kişidir, \%35.9'u ise bekârlardan oluşmakta olup 79 kişidir. Araştırmaya katılanların \%13.2' si ilköğretim mezunu olup 29 kişiden oluşmaktadır, \% 20.5'i lise mezunu olup 45 kişiden oluşmaktadır, \% 8.6's1 yüksekokul mezunu olup 19 kişiden oluşmaktadır, \% 52.7'si lisans mezunu olup 116 kişiden oluşmaktadır, \% 5'i ise lisansüstü eğitim almış olup 11 kişiden oluşmaktadır. Araştırmaya katılanların \% 34.1'i 18-31 yaş aralığında olup 76 kişiden oluşmaktadır, \% 33.2'si 31-41 yaş aralığında olup 73 kişiden oluşmaktadır, \% 27.3'ü 41-51 yaş aralığında olup 60 kişiden oluşmaktadır, \% 5'i 51-61yaş aralığında olup 11 kişiden oluşmaktadır. Araştırmaya katılanların \%19.5'i 0-5 yıl arasında çalışmakta olup 43 kişiden oluşmaktadır. \%37.7'si 5-10 y1l arasında çalı̧̧makta olup 83 kişiden oluşmaktadır. \% 10.5'i 10-15 yıl arasında çalışmakta olup 23 kişiden oluşmaktadır.\% 15'i 15-20 yıl arasında çalışmakta olup 33 kişiden oluşmaktadır. \% 17.3'ü 20 yll ve üzeri süredir çalışmakta olup 38 kişiden oluşmaktadır. Araştırmaya katılanların \% 42.3'ü işçi ve diğer olarak çalışmakta olup 93 kişiden oluşmaktadır, \%24.5'i memur olarak çalışmakta olup 54 kişiden oluşmaktadır, \% 5'i şef/birim sorumlusu olarak çalışmakta olup 11 kişiden oluşmaktadır, \% 25.6's1 uzman olarak çalışmakta olup 56 kişiden oluşmaktadır, \% 2.7'si ise şube müdürü. ve şube müdür yardımcısı olarak çalışmakta olup 6 kişiden oluşmaktadır.

Tablo 2. Cinsiyet Değişkenine İliş̧in Bulgular

\begin{tabular}{llllllll}
\hline & Grup & N & Ort. & $\begin{array}{l}\text { Std. } \\
\text { Sapma }\end{array}$ & t & sd & p \\
\hline Y.D. & Erkek & 152 & 3,0773 &, 95997 & $-2,189$ & 218 &, 03 \\
& Kadın & 68 & 3,3860 &, 98158 & $-2,170$ & & \\
İ.P. & Erkek & 152 & 4,3487 &, 59950 &, 605 & 218 &, 546 \\
& Kadın & 68 & 4,2941 &, 65782 &, 584 & & \\
\hline
\end{tabular}

Katılımcılar arasında kadınların yaşam doyumu düzeyleri $(\overline{\mathrm{x}}=$ $3,3860)$, erkeklerin yaşam doyumu düzeylerinden $(\bar{x}=$ 3,0773 ) daha yüksektir. İstatistiksel olarak da, erkek ve kadın işgörenlerin yaşam doyumu düzeyleri arasında anlamlı bir fark bulunmuştur $(\mathrm{p}<0.05)$. Dolayısıyla, yaşam doyumu düzeyleri katılımcıların cinsiyetlerine göre farklılık göstermektedir. H1aHipotezi kabul edilmiştir.

Katılımcılar arasında erkeklerin işgören performansı düzeyleri ( $\bar{x}=4,3487)$, kadınların işgören performansı düzeylerinden $(\bar{x}=4,2941)$ daha yüksektir. Ancak İstatistiksel olarak, erkek ve kadın işgörenlerinişgören performansı düzeyleri arasında anlamlı bir fark bulunamamışıı ( $>0.05)$. Dolayısıyla, işgören performansı düzeyleri katılımcıların cinsiyetlerine göre farklılık göstermemektedir. H1bHipotezi reddedilmiştir.

Tablo 3. Medeni Durum Değişkenine İlişkin Bulgular

\begin{tabular}{llllllll}
\hline & Grup & N & Ort. & $\begin{array}{l}\text { Std. } \\
\text { Sapma }\end{array}$ & t & sd & p \\
\hline & Evli & 141 & 3,3103 &, 91070 & 2,840 & 218 &, 005 \\
Y.D. & Bekâr & 79 & 2,9272 & 1,04172 & 2,735 & & \\
& & & & & & & \\
& Evli & 141 & 4,3706 &, 59582 & 1,246 & 218 &, 214 \\
I. P. & Bekâr & 79 & 4,2627 &, 65155 & 1,215 & & \\
\hline
\end{tabular}

Katılımcılar arasında evlilerin yaşam doyumu düzeyleri $(\overline{\mathrm{x}}=$ 3,3103), bekârların yaşam doyumu düzeylerinden ( $\bar{x}=$ 2,9272 ) daha yüksektir. İstatistiksel olarak da, evli ve bekâr işgörenlerin yaşam doyumu düzeyleri arasında anlamlı bir fark bulunmuştur $(\mathrm{p}<0.05)$. Yaşam doyumu düzeyleri katılımcıların medeni durumlarına göre farklı1lı göstermektedir. H2aHipotezi kabul edilmiştir.

Katılımcılar arasında evlilerin işgören performansı düzeyleri $(\bar{x}=4,3706)$, bekârların işgören performansı düzeylerinden $(\overline{\mathrm{x}}=4,2627)$ daha yüksektir. Ancak İstatistiksel olarak, evli ve bekâr işgörenlerin işgören performansı düzeyleri arasında anlamlı bir fark bulunamamıştır $\quad(p>0.05)$. İşgören performansı düzeyleri katılımcıların medeni durumlarına göre farklılık göstermemektedir. H2bHipotezi reddedilmiştir. 
Tablo 4. Eğitim Durumu Değişkeni İle İlgili Bulgular

\begin{tabular}{lllll}
\hline & $\begin{array}{l}\text { ÖğrenimDuru } \\
\text { mu }\end{array}$ & N & Ort. & $\begin{array}{c}\text { Std. } \\
\text { Sapma }\end{array}$ \\
\cline { 2 - 5 } Yaşam & İlköğretim & 29 & 2,6207 & 1,10522 \\
Doyumu & Lise & 45 & 2,9389 & 1,10159 \\
& Yüksekokul & 19 & 2,6974 &, 77091 \\
& Üniversite & 116 & 3,4720 &, 77584 \\
& Lisansüstü & 11 & 3,2500 & 1,20934 \\
& Toplam & 220 & 3,1727 &, 97500 \\
İşgören & İlköğretim & 29 & 4,1207 &, 36364 \\
Per. & Lise & 45 & 4,1333 &, 70227 \\
& Yüksekokul & 19 & 3,9737 &, 89712 \\
& Üniversite & 116 & 4,4914 &, 51386 \\
& Lisansüstü & 11 & 4,6364 &, 60584 \\
& Toplam & 220 & 4,3318 &, 61712 \\
\hline
\end{tabular}

Üniversite mezunu olan işgörenlerin yaşam doyumu düzeylerinin $(\overline{\mathrm{x}}=3,4720)$, diğer seviyedeki mezun olan işgörenlerin (lisansüstü $\quad \overline{\mathrm{x}}=3,2500$, lise $\overline{\mathrm{x}}=2,9389$, yüksekokul $\overline{\mathrm{x}}=2,6974$ ve ilköğretim $\overline{\mathrm{x}}=2,6207$ ) yaşam doyumu düzeylerinden daha yüksek bulunduğu görülmektedir.

Lisansüstü mezunu olan işgörenlerin işgören performansı düzeylerinin $(\bar{x}=4,6364)$, diğer seviyedeki mezun olan işgörenlerin (üniversite $\overline{\mathrm{x}}=4,4914$, lise $\overline{\mathrm{x}}=4,1313$, ilköğretim $\overline{\mathrm{x}}=4,1207$, yüksekokul $\overline{\mathrm{x}}=3,9737$ ) işgören performansı düzeylerinden daha yüksek bulunduğu görülmektedir.

Tablo 5. Katılımcıların Öğrenim Durumlarına Göre Yaşam Doyumu Düzeylerine İlişkin Varyans Analizi

\begin{tabular}{|c|c|c|c|c|c|c|c|}
\hline \multirow{4}{*}{ Y.D. } & & $\begin{array}{l}\text { Kareler } \\
\text { Top. }\end{array}$ & Sd & $\begin{array}{l}\text { Kareler } \\
\text { Ort. }\end{array}$ & $\mathbf{F}$ & $\mathbf{P}$ & $\begin{array}{l}\text { Anl } \\
\text { Fark }\end{array}$ \\
\hline & $\begin{array}{l}\text { Gruplar } \\
\text { arası }\end{array}$ & 26,046 & 4 & 6,511 & 7,686 & ,000 & $\begin{array}{l}1-4, \\
2-4,\end{array}$ \\
\hline & $\begin{array}{l}\text { Gruplar } \\
\text { içi }\end{array}$ & 182,141 & 215 & 847 & & & \\
\hline & Toplam & 208,186 & 219 & & & & \\
\hline \multirow{3}{*}{ İ.P. } & $\begin{array}{l}\text { Gruplar } \\
\text { arası }\end{array}$ & 9,476 & 4 & 2,369 & 6,890 & ,000 & $\begin{array}{l}2-4 \\
3-4\end{array}$ \\
\hline & $\begin{array}{l}\text { Gruplar } \\
\text { ici }\end{array}$ & 73,926 & 215 & ,344 & & & \\
\hline & Toplam & 83,402 & 219 & & & & \\
\hline
\end{tabular}

Varyans analizi testine göre katılımcıların yaşam doyumu düzeylerinin öğrenim durumlarına göre farklılaştığı görülmüştür $(\mathrm{p}<0.05)$. Bulunan bu farklılık, üniversite mezunu olan işgörenlerin yaşam doyumu düzeyleri ile ilkokul mezunu olan işgörenlerin yaşam doyumu düzeyleri arasında üniversite mezunları lehinedir. Üniversite mezunu olan işgörenlerin yaşam doyumu düzeyleri ile lise mezunu olan işgörenlerin yaşam doyumu düzeyleri arasında üniversite mezunları lehinedir ve üniversite mezunu olan işgörenlerin yaşam doyumu düzeyleri ile yüksekokul mezunu olan işgörenlerin yaşam doyumu düzeyleri arasında üniversite mezunları lehinedir. H3a Hipotezi kabul edilmiştir.

Varyans analizi testine göre katılımcıların işgören performansı düzeylerinin öğrenim durumlarına göre farklılaştığı görülmüştür $(\mathrm{p}<0.05)$. Bulunan bu farklılık, üniversite mezunu olan işgörenlerinişgören performansı düzeyleri ile lise mezunu olan işgörenlerinişgören performansı düzeyleri arasında üniversite mezunları lehinedir. Üniversite mezunu olan işgörenlerinişgören performansı düzeyleri ile yüksekokul mezunu olan işgörenlerinişgören performansı düzeyleri arasında üniversite mezunları lehinedir. H3b Hipotezi kabul edilmiştir.

Tablo 6. Yaş Değişkenine İlişkin Bulgular

\begin{tabular}{lllll}
\hline & $\begin{array}{l}\text { Görev } \\
\text { Unvanı }\end{array}$ & $\mathbf{N}$ & Ort. & $\begin{array}{l}\text { Standart } \\
\text { Sapma }\end{array}$ \\
\cline { 2 - 5 } & $18-31$ & 76 & 2,9145 & 1,02270 \\
Yaşam & $31-41$ & 73 & 3,3870 &, 96108 \\
Doyumu & $41-51$ & 60 & 3,2208 &, 87102 \\
& $51-61$ & 11 & 3,2727 &, 99029 \\
& Toplam & 220 & 3,1727 &, 97500 \\
\cline { 2 - 3 } & $18-31$ & 76 & 4,2105 &, 61516 \\
İşören & $31-41$ & 73 & 4,3836 &, 52718 \\
Per. & $41-51$ & 60 & 4,4083 &, 57484 \\
& $51-61$ & 11 & 4,4091 & 1,17406 \\
& Toplam & 220 & 4,3318 &, 61712 \\
\hline
\end{tabular}

31-41 yaş aralığındaki işgörenlerin yaşam doyumu düzeylerinin $(\overline{\mathrm{x}}=3,3870)$, diğer yaş aralığındaki işgörenlerin (51-61 $\overline{\mathrm{x}}=3,2727,41-51 \quad \overline{\mathrm{x}}=3,2208,18-31$ y1l $\overline{\mathrm{x}}=2,9145)$ yaşam doyumu düzeylerinden daha yüksek bulunduğu görülmektedir.

51-61 yaş aralığındaki işgörenlerin işgören performansı düzeylerinin $(\overline{\mathrm{x}}=4,4091)$, diğer yaş aralığındaki işgörenlerin (41-51 $\overline{\mathrm{x}}=4,4083,31-41 \quad \overline{\mathrm{x}}=4,3836,18-31$ y1l $\overline{\mathrm{x}}=4,2105)$ işgören performansı düzeylerinden daha yüksek bulunduğu görülmektedir.

Tablo 7. Katılımcıların Yaş Durumlarına Göre Yaşam Doyumu Düzeylerine İlişkin Varyans Analizi

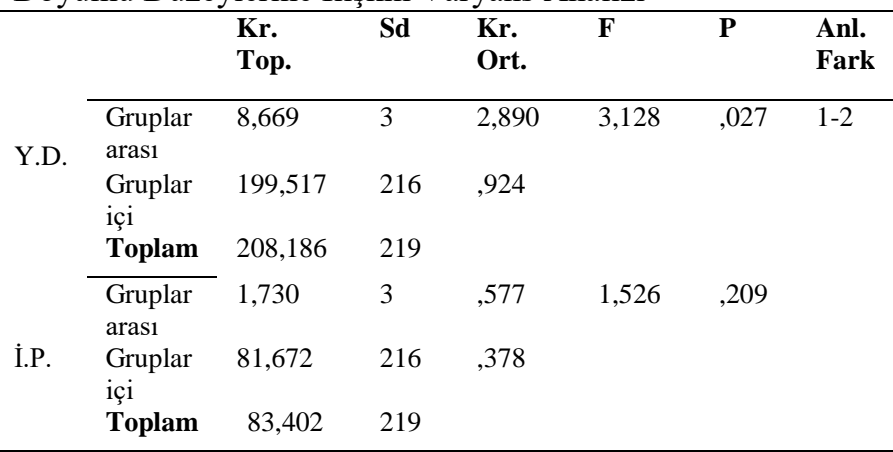

Varyans analizi testine göre katılımcıların yaşam doyumu düzeylerinin yaş aralığı durumlarına göre farklılaştığ görülmüştür $(\mathrm{p}<0.05)$. Bulunan bu farklılık, 18-31 yaş aralığı olan işgörenlerin yaşam doyumu düzeyleri ile 31-41 yaş aralığında olan işgörenlerin yaşam doyumu düzeyleri arasında 31-41 yaş aralığında olan işgörenlerin lehinedir. H4a Hipotezi kabul edilmiştir.

Varyans analizi testine göre katılımcıların işgören performansı düzeylerinin yaş aralığı durumlarına göre farklılaşmadığı görülmüştür $\quad(p>0.05)$. H4b Hipotezi reddedilmiştir. 
Tablo 8. Çalışma Süresi Değişkenine İlişkin Bulgular

\begin{tabular}{lllll}
\hline & $\begin{array}{l}\text { GörevUnva } \\
\text { nı }\end{array}$ & N & Ort. & $\begin{array}{l}\text { StandartS } \\
\text { apma }\end{array}$ \\
\cline { 2 - 5 } & $0-5$ & 43 & 3,1802 & 1,07643 \\
Yaşam & $5-10$ & 83 & 3,0602 &, 99663 \\
Doyumu & $10-15$ & 23 & 3,3587 &, 94696 \\
& $15-20$ & 33 & 3,5076 &, 90676 \\
& 20 ve üstü & 38 & 3,0066 &, 82913 \\
& Toplam & 220 & 3,1727 &, 97500 \\
& $0-5$ & 43 & 4,2151 &, 70200 \\
& $5-10$ & 83 & 4,3072 &, 61153 \\
İşgören & $10-15$ & 23 & 4,3043 &, 50541 \\
Performans1 & $15-20$ & 33 & 4,5227 &, 43013 \\
& 20 ve üstü & 38 & 4,3684 &, 70886 \\
& Toplam & 220 & 4,3318 &, 61712 \\
\hline
\end{tabular}

15-20 y1l ve üzeri görev yapan işgörenlerin yaşam doyumu düzeylerinin $(\overline{\mathrm{x}}=3,5076)$, diğer sürelerde görev yapan işgörenlerin (10-15 y1l $\bar{x}=3,3587,0-5$ y1l $\bar{x}=3,1802,5-10$ y1l $\bar{x}=3,0602,20$ ve üstü y1l $\bar{x}=3,0066)$ yaşam doyumu düzeylerinden daha yüksek bulunduğu görülmektedir.

15-20 y1l ve üzeri görev yapan işgörenlerinişgören performansı düzeylerinin $(\overline{\mathrm{x}}=4,5227)$, diğer sürelerde görev yapan işgörenlerin (20 ve üstü y1l $\overline{\mathrm{x}}=4,3684,5-10$ yıl $\overline{\mathrm{x}}=$ 4,3072, 10-15 yıl $\bar{x}=4,3043,0-5$ yıl $\bar{x}=4,2151)$ işgören performansı düzeylerinden daha yüksek bulunduğu görülmektedir.

Tablo 9. Katılımcıların Çalışma Sürelerine Göre Yaşam Doyumu Düzeylerine İlişkin Varyans Analizi

\begin{tabular}{clllllll}
\hline & & $\begin{array}{l}\text { Kr. } \\
\text { Top. }\end{array}$ & Sd & $\begin{array}{l}\text { Kr. } \\
\text { Ort. }\end{array}$ & F & P & $\begin{array}{l}\text { A. } \\
\text { Far }\end{array}$ \\
\cline { 2 - 7 } Y.D. & Gruplararas1 & 6,597 & 4 & 1,649 & 1,759 &, 138 & - \\
& Gruplar içi & 201,589 & 215 &, 938 & & & - \\
& Toplam & 208,186 & 219 & & & & - \\
& Gruplararas1 & 1,907 & 4 &, 477 & 1,258 & \multirow{2}{*}{, 288} & \\
İ.P. & Gruplar içi & 81,495 & 215 &, 379 & & & \\
\hline
\end{tabular}

Varyans analizi testine göre katılımcıların yaşam doyumu düzeylerinin çalışma sürelerine göre farklılaşmadığı görülmüştür ( $\mathrm{p}>0.05)$. Dolayısıyla yaşam doyumu düzeyleri, işgörenlerin çalışma sürelerine göre farklılık göstermemektedir. H5a Hipotezi reddedilmiştir.

Varyans analizi testine göre katılımcıların işgören performansı düzeylerinin çalışma sürelerine göre farklılaşmadığ 1 görülmüştür $(\mathrm{p}>0.05)$. Dolayısıyla işgören performansı düzeyleri, işgörenlerin çalışma sürelerine göre farkl11ık göstermemektedir. H5b Hipotezi reddedilmiştir.
Tablo 10. Görev Unvanı Değişkenine İlişkin Bulgular

\begin{tabular}{|c|c|c|c|c|}
\hline & $\begin{array}{l}\text { Görev } \\
\text { Unvanı }\end{array}$ & $\mathbf{N}$ & Ortalama & $\begin{array}{l}\text { Standart } \\
\text { Sapma }\end{array}$ \\
\hline & $\begin{array}{l}\text { İşçi ve } \\
\text { diğer }\end{array}$ & 93 & 2,7796 & 1,00734 \\
\hline & Memur & 54 & 3,1019 & ,88823 \\
\hline & Şef-Birim & 56 & 3,7455 & ,75902 \\
\hline Yaşam & Sorumlusu & & & \\
\hline \multirow[t]{6}{*}{ Doyumu } & Uzman & 11 & 3,6818 & ,43432 \\
\hline & $\begin{array}{l}\text { Şube Md. } \\
\text { Ve Şube }\end{array}$ & 6 & 3,6250 & ,68465 \\
\hline & $\begin{array}{l}\text { Md. Yrd } \\
\text { Toplam }\end{array}$ & 220 & 3,1727 & ,97500 \\
\hline & $\begin{array}{l}\text { İşçi ve } \\
\text { diğer }\end{array}$ & 93 & 4,1075 & ,59252 \\
\hline & Memur & 54 & 4,3657 & 60406 \\
\hline & Şef-Birim & 56 & 4,5625 & 60725 \\
\hline İşgören & Sorumlusu & & & \\
\hline \multirow[t]{3}{*}{ Performans1 } & Uzman & 11 & 4,7500 & ,25000 \\
\hline & $\begin{array}{l}\text { Şube Md. } \\
\text { veŞube }\end{array}$ & 6 & 4,5833 & ,40825 \\
\hline & $\begin{array}{l}\text { Md. Yrd } \\
\text { Toplam }\end{array}$ & 220 & 4,3318 & 61712, \\
\hline
\end{tabular}

Şef- birim sorumlusu konumundaki işgörenlerin yaşam doyumu düzeylerinin ( $\overline{\mathrm{x}}=3,7455)$, diğer konumlardaki işgörenlerin (uzman $\overline{\mathrm{x}}=3,6818$, Şube müdürü-Şube müdür yardımc1sı $\overline{\mathrm{x}}=3,6250$, memur $\overline{\mathrm{x}}=3,1019$, işçi ve diğer $\overline{\mathrm{x}}=$ 2,7796) yaşam doyumu düzeylerinden daha yüksek bulunduğu görülmektedir.

Uzman konumundaki işgörenlerinişgören performansı düzeylerinin $(\overline{\mathrm{x}}=4,7500)$, diğer konumlardaki işgörenlerin (Şube müdürü-Şube müdür yardımcısı $\bar{x}=4,5833$, şef- birim A. sorumlusu $\overline{\mathrm{x}}=4,5625$, memur $\overline{\mathrm{x}}=4,3657$, işçi ve diğer $\overline{\mathrm{x}}=$ Fark4 1075) işgören performansı düzeylerinden daha yüksek bulunduğu görülmektedir.

Tablo 11. Katılımcıların Görev Unvanlarına Göre Yaşam Doyumu Düzeylerine İlişkin Varyans Analizi

\begin{tabular}{|c|c|c|c|c|c|c|c|}
\hline \multirow{3}{*}{ Y.D. } & & $\begin{array}{l}\text { Kr. } \\
\text { Top. }\end{array}$ & Sd & $\begin{array}{l}\text { Kr. } \\
\text { Ort. }\end{array}$ & $\mathbf{F}$ & $\mathbf{P}$ & $\begin{array}{l}\text { A. } \\
\text { Fark }\end{array}$ \\
\hline & Gruplararas1 & 37,099 & 4 & 9,275 & 11,655 & , 000 & $\begin{array}{l}1-3, \\
1-4, \\
2-3 \\
2-4\end{array}$ \\
\hline & Gruplar içi & 171,087 & 215 & ,796 & & & \\
\hline \multirow{4}{*}{ İ.P. } & Toplam & 208,186 & 219 & & & & \\
\hline & Gruplararas1 & 10,024 & 4 & 2,506 & 7,343 & ,000 & $\begin{array}{l}1-3 \\
1-4\end{array}$ \\
\hline & Gruplar içi & 73,378 & 215 & ,341 & & & \\
\hline & Toplam & 83,402 & 219 & & & & \\
\hline
\end{tabular}

Varyans analizi testine göre katılımcıların yaşam doyumu düzeylerinin görev unvanına göre farklılaştığı görülmüştür ( $p<0.05$ ). Bulunan bu farklılık, işçi ve diğer görev unvanında olan işgörenlerin yaşam doyumu düzeyleri ile şef -birim sorumlusu görev unvanında olan işgörenlerin yaşam doyumu düzeyleri arasında şef -birim sorumlusu görev unvanındakiler lehinedir. İşçi ve diğer görev unvanında olan işgörenlerin yaşam doyumu düzeyleri ile uzman görev unvanında olan işgörenlerin yaşam doyumu düzeyleri arasında uzman görev unvanındakiler lehinedir. Memur görev unvanında olan işgörenlerin yaşam doyumu düzeyleri ile şef -birim sorumlusu görev unvanında olan işgörenlerin yaşam doyumu düzeyleri arasında şef -birim sorumlusu görev unvanındakiler 
lehinedir. Memur görev unvanında olan işgörenlerin yaşam doyumu düzeyleri ile uzman görev unvanında olan işgörenlerin yaşam doyumu düzeyleri arasında uzman görev unvanındakiler lehinedir. H6a Hipotezi kabul edilmiştir.

Varyans analizi testine göre katılımcıların işgören performansı düzeylerinin görev unvanına göre farklılaştığ görülmüştür $(\mathrm{p}<0.05)$. Bulunan bu farklılık, işçi ve diğer görev unvanında olan işgörenlerin işgören performans düzeyleri ile şef -birim sorumlusu görev unvanında olan işgörenlerin işgören performans düzeyleri arasında şef -birim sorumlusu görev unvanındakiler lehinedir. İşçi ve diğer görev unvanında olan işgörenlerinişgören performansı düzeyleri ile uzman görev unvanında olan işgörenlerinişgören performansı düzeyleri arasında uzman görev unvanındakiler lehinedir. H6b Hipotezi kabul edilmiştir.

\subsubsection{Faktör Analizi}

Tablo 12. Yaşam Doyumu İçin KMO ve Bartlett Testi

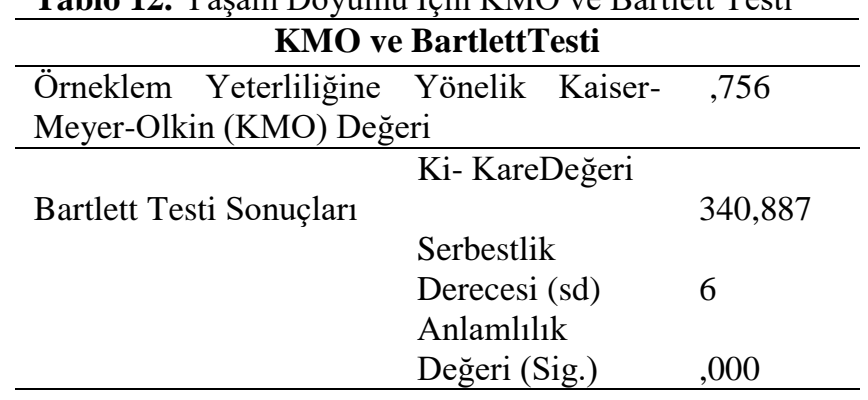

Yapılan çalışmada anket soruları KMO testi doğrultusunda incelenmiş ve değeri 0,756 olarak belirlenmiştir. Örneklemin yeterliliği çok iyi olarak değerlendirebilir.

Barlett testi sonuçları da $(\mathrm{p}<01)$; verilerin normal dağılıma sahip olduğunu göstermektedir. Varyansın toplam \% 55,692' si açıklanmaktadır.

Tablo 13. İşgören Performansı İçin Faktör Analizi

\begin{tabular}{lll}
\hline \multicolumn{3}{c}{ KMO ve BartlettTesti } \\
\hline $\begin{array}{l}\text { Örneklem } \\
\text { Meyer-Olkin (KMO) Değeri }\end{array}$ & \multicolumn{2}{c}{ Yeterliliğine Yönelik Kaiser- } \\
\hline Bartlett & Ki- Kare Değeri & \\
Sonuçları & Testi & 389,242 \\
& $\begin{array}{l}\text { Serbestlik Derecesi } \\
\text { (sd) } \\
\text { Anlamlılık Değeri } \\
\text { (Sig.) }\end{array}$ & 6 \\
\hline
\end{tabular}

Yapılan çalışmada anket soruları KMO testi doğrultusunda incelenmiş ve değeri 0,800 olarak belirlenmiştir. Örneklemin yeterliliği çok iyi olarak değerlendirebilir.

Barlett testi sonuçlarıda $(\mathrm{p}<01)$; verilerin normal dağılıma sahip olduğunu göstermektedir. Varyansın toplam \% 60,328' i açıklanmaktadır.

\subsubsection{Korelasyon Analizi}

Yaşam doyumunun işgören performansı ile arasında anlamlı bir ilişki olup olmadığını tespit etmek amacıyla pearsonkorelasyon analizi yapılmıştır.

Tablo 14. Yaşam Doyumu ile İşgören Performansı Aralarındaki İlişkinin Korelasyon Analizi İle İncelenmesi

\begin{tabular}{clc}
\hline & \multicolumn{2}{l}{ İşgören Performansı } \\
\hline Yaşam Doyumu & $\mathbf{r}$ &, $405^{* *}$ \\
\cline { 2 - 3 } & $\mathbf{p}$ &, 000 \\
\hline
\end{tabular}

Yaşam doyumu ile işgören performansı arasında istatiksel açıdan anlamlı ve pozitif bir ilişki bulunmuştur ( $\mathrm{r}=0.405$; $\mathrm{p}=0,000<0.01$ ). Bulgular araştırmanın. 7. hipotezinin doğruluğunu göstermektedir.

\subsubsection{Regresyon Analizi}

Tablo 15. Yaşam Doyumu İle İşgören Performansı Arasındaki Doğrusal Regresyon Modelinin Bulguları

\begin{tabular}{lccccc}
\hline & $\begin{array}{c}\text { Kareler } \\
\text { top. }\end{array}$ & s.d. & $\begin{array}{c}\text { Kareler } \\
\text { Ort. }\end{array}$ & $\mathrm{F}$ & $\mathrm{p}$ \\
\hline Regresyon & 13,660 & 1 & 13,660 & &, 000 \\
Hata & 69,742 & 218 &, 320 & & \\
Toplam & 83,402 & 219 & & & \\
\hline $\mathrm{R}$ &, 405 & $\mathrm{R}^{2}, 164$ & & Düz. R &, 160 \\
\hline
\end{tabular}

Tablo 16. Doğrusal Regresyon Modeli İçin ANOVA ve Belirleme Katsayısı Bulguları

\begin{tabular}{lcccc}
\hline & \multicolumn{3}{c}{ std. } \\
& Katsayılar & Katsayılar & T & p \\
\hline Sabit & 3,519 & & 27,052 &, 000 \\
$\begin{array}{l}\text { Yaşam } \\
\text { Doyumu ort. }\end{array}$ &, 256 & 40,5 & 6,535 & \\
\hline
\end{tabular}

Yaşam doyumu ile işgören performansı arasındaki doğrusal regresyon modelinin anlamlılığı ANOVA testi ile incelenmiştir. ANOVA testine göre model istatistiksel olarak anlamlı bulunmuştur. Buna göre yaşam doyumu ile işgören performansı arasındaki ilişki doğrusal regresyon modeliyle incelenebilir. Ayrıca model için düzeltilmiş $\mathrm{R}^{2}$ katsayısı 0,160 olarak hesaplanmıştır. Bu değer, işgören performansı değişkenliğinin \%16'sının doğrusal regresyon modeli aracılığıyla yaşam doyumu tarafından açıklandığını göstermektedir

Yaşam doyumu ile işgören performansı arasındaki doğrusal regresyon modelinin katsayılarının tahmini bulgulara göre, yaşam doyumunun katsayıları istatistiksel olarak anlamlı bulunmuştur. Buna göre işgören performansı $\mathrm{Y}$, yaşam doyumuna $\mathrm{X}^{1}$ ile gösterilirse doğrusal regresyon modeli;

$\mathrm{Y}=3,519+0,256 * \mathrm{X}^{1}$ olarak elde edilir.

Yaşam doyumu doğrusal yönde yani pozitif olarak Y'yi \% 40,5 oranında etkilemektedir. 


\section{Sonuç ve Öneriler}

$\mathrm{Bu}$ araştırma yaşam doyumunun işgören performansı üzerindeki etkilerini ortaya koymaktadır. Başka bir şekilde ifade edilecek olursa; yaşam doyumunun işgören performansı üzerinde anlamlı bir etkisi olup olmadığına ve demografik değişkenler açısından anlamlı bir farklılığın olup olmadığına Ankara İli Gençlik ve Spor Müdürlüğü'nde gerçekleştirilen çalışma ile yanıt aranmaktadır. Araştırma sonuçları değerlendirildiğinde yaşam doyumu ile işgören performansı arasında pozitif ve anlamlı bir ilişki olduğu ve işgören performansını etkilediği, demografik değişkenler açısından yaşam doyumunun katılımcıların cinsiyet, medeni durum, yaş, öğrenim durumu ve görev unvanları arasında anlamlı bir farklılık olduğu, sadece çalışma süreleri açısından herhangi bir anlamlı farklılığın olmadığı, işgören performansının katılımcıların öğrenim durumu ve görev unvanları arasında anlamlı bir farklılık olduğu, nedeni durum cinsiyet, yaş ve çalışma süreleri açısından herhangi bir anlamlı farklılığın olmadığı tespit edilmiştir.

Yapılan çalışma sonucunda yaşam doyumu ile işgören performansı arasında bir ilişki olduğu ve bu ilişkinin katsayısının $\mathrm{r}^{2}$ değeri 0.16 olduğu tespit edilmiştir. Yaşam doyumunun iş doyumunu $\% \quad 40,5$ oranında etkilediği anlaşılmıştır.

Çalışma, daha önce yapılan; Jones., (2006), Kale (2015), Özer ve Doğan (2017), Çınar ve Özyılmaz (2018) yapmış oldukları çalışmaları destekleyici niteliktedir. Yapılan çalışma değişkenler arası pozitif bir ilişkinin olduğunun görülmesi yaşam doyumu seviyesinin arttıkça işgören performansının artacağı sonucunu göstermektedir. Bu durum özel ve kamuda yönetici pozisyonunda bulunanların işgörenlerin performanslarının artırılması amacıyla faydalanabilecekleri önemli bir konuya dikkat çekmektedir.

Organizasyonların bulundukları sektörde söz sahibi olmak ve rakiplerinin gerisine düşmemeleri için uzun vadeli hedeflerinin olması gerekmektedir. Bu hedeflere ulaşmak için görev yapan personelin sergileyeceği performans anahtar rol taşımaktadır. Çeşitli faktörler işgörenlerin performansı üzerinde olumlu ve olumsuz etki oluşturabilmektedir. Olumlu faktörlerin uygulamaya konulması ve olumsuz faktörlerin ise kaldırılmasına yönelik çalışmalar yürütmek yöneticilerin görevleri arasındadır.

Yaşam doyumunun artırılması da işgören performansının artırılmasına etki eden önemli faktörlerden birisidir. İnsanların iş hayatının dışında hem aile hayatı hem de sosyal hayatı bulunmaktadır. İş dışında karşıllaşılan sorunlar ve doyumsuzluk halini gizlemek ve işe yansıtmamak oldukça zordur. Nitekim insanlar duyguları oldukça güçlü olan canlılardır ve iş ve iş dışı yaşantısıyla bir bütün olarak değerlendirilmelidir. İşgörenlerin ruh hallerini etkileyen sorunların ortadan kaldırılması, huzurlu olmalarının ve hayata pozitif bakabilmeleri için yöneticilerin her türlü desteği sağlamaları ve yaşam doyumunu artırmaya yönelik çalışmalar yapmaları hem işgörenler hem de organizasyonun menfaati açısından oldukça önemlidir.

Bu çalışma, Ankara ili Gençlik ve Spor Müdürlüğü’nde çalışan personelin yaşam doyumunun, işgören performansı üzerindeki etkisini ortaya koymaktadır. Çalışma aynı zamanda kapsamı açısından, yaşam doyumunun işgören performansı üzerinde etkisini araştıracak olan gelecek çalışmalara da katkı sağlayacaktır.

\section{Kaynakça}

Bekiş, T., Bayram A.,\& Şeker, M. (2013). "Kurumsal İtibarın İşgören Performansı Üzerindeki Etkisinin Belirlenmesine Yönelik Bir Araştırma", Uluslararası Alanya İşletme Fakültesi Dergisi, Cilt:5, Sayı:2, 19-27.

Benligiray, S. (2011). İnsan kaynaklarının yönetimi, Anadolu Üni. Eskişehir

Boylu, Y.,\& Sökmen, A. (2002). Sınır Birim İş görenlerinin Performans Değerlendirme Kriterlerine Bakışı: Ankara'daki Otel İşletmeleri Üzerine Bir Uygulama. Gazi Üniversitesi Ticaret ve Turizm Eğitim Fakültesi Dergisi, 2, 167-182.

Çınar, Ö.,\& Özyılmaz, F. Z.(2019). İş Tatmini İle Yaşam Tatmini Arasındaki İlişki: Bayburt Üniversitesinde Bir Uygulama.Iğd. Üniv. Sos Bil Der, No:17, 533-556.

Dağlı A.,\& Baysal, N. (2016). Yaşam Doyumu Ölçeğinin Türkçe'yeUyarlanması: Geçerlik ve Güvenirlik Çalışması. Elektronik Sosyal Bilimler Dergisi, 15(59): 1250-62.

Dehaghi, M. R.,\&Rouhani, A. (2014), Studying the Relationship between the Effective Factors on Employees' Performance in Iran's University and the Students' Satisfaction with regards to Employees' Performance ${ }^{e}$ Procedia Social and Behavioral Sciences 141, 903 - 908 .

Diener, E.,Emmons, R. A., Larsen, R. J., \&Griffin, S. (1985). The Satisfaction with Life Scale. Journal of Personality Assessment, 49, 71-75.

Dost, M.T. (2007). "Üniversite Öğrencilerinin Yaşam Doyumunun Bazı Değişkenlere Göre İncelenmesi”, Pamukkale Üniversitesi Eğitim Fakültesi Dergisi, 2(22); 132-143.

Dündar, S. (1993). "Teorik Çerçeve İçinde Yaşamdan Duyulan Tatmin Kavramı”, Yönetim Dergisi, Y11: 4, Sayı: $15,49-54$.

Engin, H. (2008). Kamuda İnsan Kaynakları Planlaması Olarak Norm Kadro, Kocaeli: Kocaeli Üniversitesi Sosyal Bilimler Enstitüsü, Yüksek Lisans Tezi.

Jones M.D.(2006). "Which is a Better Predictor of Job Performance: Job Satisfactionor Life Satisfaction?", Journal of Behavioral and Applied Management, Vol.8, Iss. 1, 20-42

Kale, E. (2015). "Lider Desteği ve İş Arkadaşları Desteğinin İş Performansı Üzerine Etkileri: İş Tatmini ve Yaşam Tatmininin Arac1 Rolü’, International Journal of Economic \& AdministrativeStudies, 7(14), 103-119.

Kirkman, B.L.,\&Roren, B. (1999).Beyond Self-Management: Antecedentsand Consequences of Team Empowerment, Academy of Management Journal, 42, 58-74.

Neugarten BL.,Havighurst RJ.,\&Tobin, SS. (1961) Theme asurement of life satisfaction. Journal J Gerontol 16:134143 . 
Sigler, T.H. \&Pearson C. M. (2000). "Creating An Empowering Culture: Examining the Relationship Between Organizational Culture and Perceptions of Empowerment" Journal of Quality Management, 5:27-52.

Özer, K, E.,\& Doğan, E. (2017). "Yaşam Doyumu ve Performans İlişkisi: Adıyaman Üniversitesi Akademik Personeli Uygulaması", Vol:3, Issue:13; 307-315 (ISSN:2149-8598)

Özer, M.,\& Karabulut, Ö.Ö. (2003). "Yaşlılarda Yaşam Doyumu", Turkish Journal of Geriatrics, 6(2); 72-74.

Turnalı, D. (2013) İnsan Kaynakları Yönetiminde Örgütsel Bağlılığın İşgören Performansı Üzerine Etkisi, İstanbul: Beykent Üniversitesi

Tutar, H.,\& Altınöz, M. (2007). Örgütsel iklimin işgören performansı üzerine etkisi: Ostim imalat işletmeleri çalışanları üzerine bir araștırma, Ankara Üniversitesi SBF Dergisi, 65(2), 195-218.

Wang, G. \&Netemeyer, R.G. (2002). The Effects of Job Autonomy, Customer Demandingness and Trait Competitiveness on Salesperson Learning, Self-Efficacy and Performance, Journal of the Academy of Marketing Science, 30 (3): 217-228.

Veenhoven, R. (1996). "Developments in Satisfaction Research" Social IndicatorsResearch, Vol. 37

Zhao, X.,Qu, H., \& Richard, G., (2011). "Examining the Relationship of Work-Family Conflict to Job and life Satisfaction: A Case of Hotel SalesManagers", International Journal of Hospitality Management, Vol. 30, Iss. 1, 46-54. 